\title{
A Dynamic Capabilities-Based Research Model for Innovation in Independent Restaurants
}

\author{
Belinda K. Muriuki ${ }^{1}$, Zack B. Awino ${ }^{1}$, Madara M. Ogot ${ }^{2} \&$ James N. Muranga $^{1}$ \\ ${ }^{1}$ School of Business, University of Nairobi, Nairobi, Kenya \\ ${ }^{2}$ Department of Mechanical Engineering, University of Nairobi, Nairobi, Kenya \\ Correspondence: Belinda K. Muriuki, School of Business, University of Nairobi, Nairobi, Kenya.
}

Received: August 30, 2021

doi:10.5539/ibr.v14n12p135
Accepted: November 26, $2021 \quad$ Online Published: November 29, 2021

URL: https://doi.org/10.5539/ibr.v14n12p135

\begin{abstract}
The purpose of the study is to contribute to the existing literature by reviewing empirical studies conducted in the restaurant industry on innovation to develop a dynamic capabilities-based research model for independent restaurants which can be tested by future scholars in the restaurants industry. The review covered innovation models that have been used and tested in restaurants; types of innovation; dynamic capabilities as an antecedent for innovation; the mediating role of human capital between dynamic capabilities and innovation; and the relationship between innovation and performance. The results of the study revealed that innovation activities described in the literature can be categorised into the dynamic capabilities components of sensing, learning, integrating, and co-ordinating capabilities thus supporting the proposed dynamic capabilities research model. The model, therefore, provides a comprehensive framework for investigating innovation activities in independent restaurants.
\end{abstract}

Keywords: dynamic capabilities, human capital, innovation, performance, restaurants

\section{Introduction}

The restaurant sector is important in the economic development and employability in many countries (Hallak, Assaker, O’Connor, \& Lee, 2018, Otengei, Bakunda, Ngoma, Ntayi \& Munene, 2017). In Australia, for example, the industry generated $\mathrm{A} \$ 23.5$ billion in 2016 and was the second-largest employer in the tourism sector (Assaf, Deery \& Jago, 2011). In the United States of America, the industry employed 14.4 million persons in 2016 (American Restaurant Association, 2016), generated US\$ 78.3 billion, and was the largest employing sector. In Kenya, the industry represents 11.6 per cent (1.6 million) of those employed by Small and Medium Enterprises (Kenya National Bureau of Statistics, 2018). However, the industry is faced with difficulties in maintaining long-term sustainability and many close within the first five years of operation (Otengei et al., 2017; Lee, Hallack \& Sardeshmukh, 2016). The challenges faced include increased competition, limited resources and capabilities, rapidly changing customer preferences, and inability to consistently provide unique products and services. Further, consumers make decisions on the choice of restaurants to dine based on previous customer reviews and ratings on the restaurants' websites and online platforms (Singal, 2015).

There are several features that have been used by scholars to describe an independent restaurant. The common features include size of the restaurant; type of menu; type of service and ownership. Independent restaurants are small, individually owned and have distinct features in aesthetics and menu type. Their processes are informal and may not invest a lot of resources to evaluate and select their locations as notable in restaurants chains (Harris et al, 2014; Camillo et al., 2008). The ratio of managers to employees is greater in chain restaurants compared to independent restaurants mainly due to their larger resource base (Gordon \& Parish,2021). Some studies have focused on studying a set of dimensions that describes independent restaurant such as type, style of menu and service, sector, cuisine and proprietorship (Canziani et al., 2016). Some have used cuisines from a specific country that customers view as popular and authentic (Liu, Li, DiPietro \& Levitt, 2018). Others have used type of service price charged for meals and individual ownership that fits the description of a small-scale restaurant. This study will focus on all independent restaurants in general to determine how the model would work in different restaurant settings.

Customer reviews and ratings demonstrate the customer satisfaction levels of repeat and new customers. Service 
levels may vary due to employees with different levels of capabilities and the resources available to provide unique products and services. Hence high levels of innovation embraced by the restaurant industry, competitive development of their resources and their capabilities is critical for their long-term success. Many restaurant owners need to recognise the important role innovation plays in achieving competitiveness, embrace it fully and integrate it with restaurant capabilities to respond to the external environmental demands and customer needs (Hallak et al., 2018). Numerous studies have developed dynamic capabilities-based models and demonstrated their impact on performance. For example, Zahra, Sapienza, \& Davidsson (2006) used resource, knowledge, selection and learning processes that were influenced by a company's entrepreneurial activities and classified them to applicable dimensions of dynamic capabilities and the organisation's knowledge. Salunke, Weerawardena, \& McColl-Kennedy (2011) created a dynamic capability innovation-based model for use by entrepreneurs to build their dynamic capabilities, increase their innovation and sustain their competitiveness in a dynamically changing business environment. Development of models, therefore, that create, modify, and extend dynamic capabilities is critical to increase innovation and sustain competitive advantage. This research adds to the body of knowledge on innovation in the restaurant sector by developing a dynamic capabilities-based research model applicable in dynamic business environments in which independent restaurants operate. The proposed model is compared to existing models on innovation in the restaurant sector.

\section{Literature Review}

The review focused on previously developed innovation models for restaurants. Innovation is important for the achievement of the restaurant industry's competitiveness due to the nature of its products that can easily be imitated by rivals. Competitive rivalry is high resulting in early restaurant closures. Studies have shown that innovation can be a key source of a company's competitiveness and long-term sustainability (Lee, Hallak \& Sardeshmukh, 2016; Zhou, Hong \& Liu, 2013). Innovation is the ability to generate, accept and implement new ideas that are not limited to products, services, processes, management methods and marketing. Innovation is conceptualized as a means of achieving organizational change in response to change in the environment. Also, idea generation is fundamental to a firm's innovation development process. These come from company employees and research and development carried out within or outside the company (Zhou et al., 2013). For example, dining in a competitor's restaurants and obtaining ideas from customers (Lee et al., 2016).

Research on restaurant innovation has increased over time. In the past, studies were purely descriptive and focused on new product and service innovation (Ottenbacher \& Gnoth, 2005; Ottenbacher \& Harrington, 2007; Ottenbacher \& Harrington, 2009; Stierand, Dorfler, \& Macbryde, 2014). More recently, empirical studies have investigated the link between innovation and performance. For example, Hallack et al. (2018) proposed and tested a model to determine the effect of creative self-efficacy, resilience, restaurant owners experience, and innovation on performance. The model by Lee et al. (2016) investigated the link between entrepreneurship and innovation on small restaurant performance. Barriers which impede a restaurant's level of innovation include; inadequate research and development investments; limited protection of intellectual property, inadequate resources; inadequate experienced and knowledgeable human capital, limited working capital and high cost of developing innovation (Lee et al., 2016; Lee, Hallak \& Sardeshmukh, 2019). Valeri \& Baggio (2021) study on Italian intermediaries within the tourism industry focused on how information and knowledge acquired from various channels would flow within the Italian intermediary network in an efficient manner and increase innovation among the various players of the Italian tourism intermediary network.

Organization for Economic Cooperation and Development (OECD) studies have provided rules that classify innovation into various categories namely: product, service, process, marketing and management innovations (Hall, 2009). These innovations are well suited to the restaurant industry and have been used as a basis for empirical research. Some of the innovations include new menus, new service delivery systems, improved production methods, improved organograms, improved employee benefits, better management of external relations, employee career progression, and staff empowerment (Hjalager, 2010; Ottenbacher \& Harrington, 2009; Hall, 2009). A brief description of each of the OECD components follows.

Product innovation include products that are new or significantly improved. A company may focus on improving or creating new product attributes and use new materials for the production process. Ottenbacher \& Harrington (2007) established that the restaurant sector can embrace innovation through quality improvement of products and cost reduction, resulting in increased sales and profitability. Their study findings provide key insights to restaurants on the product innovation process even to those owner/managers who may understand its importance and its influence on a restaurant's level of competitiveness. Ottenbacher \& Harrington (2009) established that small quick service restaurants suffered from inadequate resources, for example trained chefs thereby affecting product quality, and had informal structures hence product innovation could not thrive. Steirand et al (2014) 
found that the head chef was the central source of creativity and the champion of product innovation in a haute cuisine restaurant.

Service innovation refers to those that are significantly improved or new such as new service delivery systems, use of technology, and new ways of engaging customers in service provision. Hussain, Konar \& Ali (2016) revealed that teamwork and knowledge sharing contributed to improved hotel's service innovation performance. The dimensions of teamwork and knowledge sharing described in his study also apply in the restaurant industry. Muriuki \& Ogot (2018) indicated that e -commerce initiatives such as restaurant websites, third-party sites, and mobile applications enabled customers to make online orders. The impact of the initiatives was increased sales and visibility hence dampening the bargaining power of channels by having direct avenues to customers and in a wider geographical space.

Process innovation includes all the operational tasks conducted to improve and enhance the quality of offerings using more cost-effective methods of delivery to increase efficiency and productivity. Some of the process innovations include procurement of new machinery, upgrading automation, acquisition of new sources of energy for production, embracement of green practices such as eco-friendly food packaging methods, conversation of energy that reduces the cost of labour and operational costs (Lee et al., 2016). Other process innovations include use of information technology to improve a customer's experience, flexible check out systems, use of point-of-sale systems and smart-phones applications for the service delivery process (Van, Victorino, Verma, Plaschka \& Dev, 2005). Chau \& Chung (2010) established that a significant relationship existed between a customer's willingness to spend more in restaurants that employ and advocate for the use of green practices than those which did not.

Marketing innovation refers to new marketing techniques and methods such as improved pricing, product designs and promotional strategies. Lee et al. (2016) established that compared to other types of innovations, management and marketing innovations affected the restaurant's performance the most. Important activities related to marketing innovation include use of technological applications such as apps; staff training and empowerment and implementation of effective succession plans. His findings were consistent with those of Gunday, Ulusoy, Kilic \& Alpkan (2011) who argued that for restaurants to remain sustainable and competitive, they must pay attention to marketing activities; restructure their administration for better coordination; create an internal environment that fosters innovative thinking and teamwork. Examples of marketing innovations in the restaurant industry include newer restaurant design to create a unique interior and exterior appearance that can draw customer attention. Wall \& Berry (2007) established that there was increased significance of customer awareness on the design of a restaurant and its environment. Ryu \& Han (2010) established that innovation in the design and ambience of a restaurant is positively linked to customer behaviour and profitability. There was also a strong correlation between restaurant's operating environment, its design with consumer's perception on the quality of service and the restaurant's pricing levels (Ryu, Lee, Gon Kim, 2012). Lee et al. (2019) established that the implementation of delivery services, happy hours, outdoor advertising, smartphone apps, use of social media to promote the businesses, online booking systems, are some of the key marketing innovations among Australian restaurants.

Finally, management innovation is the significant improvement or introduction of new methods to the management of external relationships; systems; structures and organized functions (Camisón \& Monfort-Mir, 2012; O'Sullivan \& Dooley, 2009). Newer management styles such as flexibility is a key management personality trait in the restaurant industry as it creates empathy with customers. Better relationships with external stakeholders such as suppliers have enabled managers to obtain good suggestions on the type of products to provide through use of organically grown raw supplies. Staff empowerment; better compensation; training; service orientation; customer orientation of management and employees are examples of management innovations that are critical for the success of a restaurant as they positively impact service quality and profitability (Kato, Okamuro \& Honjo, 2015; Gill, 2008).

\section{Towards a Dynamic Capabilities Innovation Model for Independent Restaurants}

\subsection{Dynamic Capabilities as Antecedents of Innovation in Restaurants}

Literature on dynamic capabilities previously focused on the development and understanding of concepts, definitions, assumptions, and applicable boundary conditions with minimal empirical studies carried out to demonstrate its operationalisation and measurability. Recent scholarly research has resulted in an increased number of empirical studies which have improved the understanding of its constructs, operationalisation, emerging methodologies, and measurement (Schilke, Hsu \& Helfat, 2018). The earlier definition of dynamic capabilities by Teece, Picano \& Shuen (1997) as the integration and configuration of company resources and 
competences external and internal to the firm to address rapid environmental changes, is the most widely definition used to date (Schilke et al., 2018). Dynamic capabilities has also been defined as the strategic routines in which organizations configure current resources to newer ones as markets evolve, die, collide, merge or split (Eisenhardt \& Martin, 2000); modification of a firm's operating capabilities to achieve increased effectiveness (Zollo \& Winter, 2002); and creation, extension and modification of zero-level capabilities and companies' asset bases (Teece, 2007).

Wang \& Ahmed (2004) defined three component factors for dynamic capabilities: adaptive capability - a firm's ability to identify and exploit emerging market opportunities; absorptive capability - ability to integrate external information into knowledge embedded in the firm; innovative capabilities - ability to align strategic innovative orientation with behaviours and processes to develop new products and services. Adaptive capabilities manifest themselves in a firm's alignment between its dynamic strategic needs and the internal organizational form. Innovative capabilities provide the link between a firm's innovativeness to its advantage in the market. Studies in the restaurant industry that have used these component factors include Otengei, Bakunda Ngoma, Ntayi \& Munene (2017) who investigated absorptive, innovative and adaptive capabilities of ethnic restaurants in East Africa and their extent of inward internationalization using an inductive approach. Their research findings heightened the heterogeneity of the dynamic capabilities approach as being context-specific. Ethnic restaurants capacity to absorb external and internal knowledge assisted them in foreign tourist attraction and retention. Innovative capabilities were the embracement of new technologies and the development of heterogeneous approaches to menu development and improved process. Adaptive capabilities focused on the abilities to provide quality food and personalized service. The challenges faced in the measurement of adaptive, absorptive, and adaptive capabilities are that their dimensions are generic and not customized for each industry. For example, the innovation capability developed in the manufacturing sector may not be applicable in the restaurant industry (Hjalager, 2010). Incorporating the work by Teece (2007) and Eisenhardt \& Martin (2000), Pavlou \& Sawy (2011) proposed and tested a four-dimensional model: sensing, learning, integrating and coordinating capabilities. Sensing capability is the ability to identify, understand and pursue opportunities in the market; learning capability is the ability to strengthen current operational capabilities with new knowledge; integrating capability is the ability to combine individual employee's knowledge into the firm's revised operational capabilities and finally coordinating capability is the ability within the new operational capabilities to deploy resources and activities. A comparison between the two sets of component factors and their corresponding dimensions is presented in Table 1. The dimensions operationalised by Pavlou \& Sawy (2011) are the most widely used in dynamic capabilities research as they provide an in-depth understanding of the environment in which a business operates and better capture activities surrounding innovation in restaurants as evidenced by the empirical literature as presented below. They were therefore adopted for this study.

Table 1. Component Factors and Dimensions of Dynamic Capabilities

\begin{tabular}{lll}
\hline Component Factors & Dimensions & References \\
\hline Sensing Capabilities & $\begin{array}{l}\text { Generating (customer needs), disseminating and responding to market } \\
\text { intelligence. }\end{array}$ & $\begin{array}{l}\text { Teece (2007); } \\
\text { Pavlov \& Sawy } \\
(2011)\end{array}$ \\
Learning Capabilities & $\begin{array}{l}\text { Acquiring, assimilating, transforming and exploiting knowledge. } \\
\text { Coordinating Capabilities }\end{array}$ & $\begin{array}{l}\text { Contribution of individual knowledge to the firm, representation of } \\
\text { individual and firm knowledge and inter-relation of diverse knowledge } \\
\text { inputs to the firm. }\end{array}$ \\
Integrating Capabilities & $\begin{array}{l}\text { Contribution (collects and combines individual inputs), representation } \\
\text { (builds a shared understanding) and inter-relation (makes routine the } \\
\text { reconfigured operational capabilities). }\end{array}$ & Wang \&Ahmed \\
Adaptive & $\begin{array}{l}\text { Identification and capitalization of new market opportunities } \\
\text { Absorptive }\end{array}$ & $\begin{array}{l}\text { Identification, recognition of the external knowledge acquired, assimilation } \\
\text { and its application for commercial use }\end{array}$ \\
Innovative & $\begin{array}{l}\text { Development of new products, markets through alignment of innovative } \\
\text { behaviour, processes with the company; strategic orientation }\end{array}$ & \\
\hline
\end{tabular}

Sensing capabilities involve the processes of generating, disseminating, and responding to market intelligence and the determination of customers' needs. Companies with strong sensing capabilities play a higher active role 
in scanning, searching, and interpreting information acquired from the environment better than their competitors (Helfat \& Peteraf, 2003). Ottenbacher \& Harrington (2009) established that firm innovation can result from internally and externally generated ideas. For example, Michelin Star chefs spent a significant amount of time scanning the environment to search for new suppliers with high quality and unique produce. External information collected for new menu development was gathered from restaurant visits, customer feedback, cooking shows, new cooking technology, experience from various employers/current employer, and customer ideas (Ottenbacher \& Harrington, 2007).

Learning capabilities are the processes of acquiring, assimilating, transforming, and exploiting knowledge. Ability to learn permits performance of activities effectively through experiment and practice thereby creating new knowledge and new solutions that inform the development of new products, services, and processes to deliver the products to consumers in a more cost-effective manner (Helfat \& Peteraf, 2003). For example, Michelin chefs rely on learning as they work on specific products. In their study, learning also involved the determination of food components to include in the final product based on the identified market trends, new production methods, presentation techniques, and ingredients. Continuous feedback mechanisms received from customers resulted in new or improved products. Menu's recipe files were also developed through photographing concepts, presentations techniques, and written instructions which could be used across the entire restaurant system (Ottenbacher \& Harrington, 2007). The theoretical model by Hallak et al. (2018) on innovation and performance in up-scale restaurants in Australia found the owners creative-self efficacy (can be considered as one of the dimensions of learning capabilities) to have had a positive relationship with innovation and a positive impact on performance.

Coordinating capabilities are processes that relate to the contribution (collecting and combining individual inputs), representation (building a shared understanding), and interrelation (making routine the reconfigured operational capabilities). Companies with strong co-ordinating capabilities allocate the right resources to activities, deploy the right individuals to perform the activity, orchestrate and build synergies among the resources and activities (Helfat \& Peteraf, 2003). In the study of Michelin Chefs, Ottenbacher \& Harrington (2007) found these capabilities to be critical during the product testing phase where the chefs co-ordinated with the managers, the wine butlers, and customers to authenticate a menu. The Manager and wine butler had a sensible food tasting capability and provided constructive feedback on food tastes and wines suitable for accompanying certain kinds of flavour combinations. Once feedback was received, the chef co-ordinated with the other kitchen staff to produce the product (Harrington, 2005).

Finally, integrating capabilities are processes that involve the contribution of individual knowledge to the firm, representation of individual and firm knowledge, and interrelation of diverse knowledge inputs to the firm. Ability to integrate requires effective combination, representation, and dissemination of an individual's knowledge into the company to create a collective understanding. Through this, managers can respond quickly to competitors' actions, understand customer needs better and more appropriately respond to novel situations (Helfat \& Peteraf, 2003). Harrington (2004) developed a menu innovation model which began from the formulation of innovation to the introduction that integrated several links and feedback mechanisms from customers and employees. Hallack et al. (2018) used the entrepreneurial resilience construct, that is very similar in many aspects to integrating capabilities, in their model of innovation and performance in restaurants. They operationalized resilience as the "dynamic adaptation process that allows entrepreneurs to continue to look towards the future despite harsh market conditions and destabilizing events, they may continually face" (Ayala and Manzano, 2014, p. 127). They found that an owner's resilience had a direct positive impact on innovation and performance. Valeri, \& Baggio (2021) study on Italian intermediaries within the tourism industry focused on how information and knowledge acquired from various channels would flow within the Italian intermediary network in an efficient manner and increase innovation among the various players of the Italian tourism intermediary network. His study enhances the dynamic capabilities dimensions of integrating capabilities which ensures knowledge and information flow within an organization is shared in a collective, logical, and interactive manner (Okhuysen \& Eisenhardt,2002).

We therefore posit the following.

Proposition 1a: The greater a restaurant's sensing capabilities, the greater the ability of and likelihood for firm innovation.

Proposition 1b: The greater a restaurant's learning capabilities, the greater the ability of and likelihood for firm innovation.

Proposition 1c: The greater a restaurant's integrating capabilities, the greater the ability of and 


\section{likelihood for firm innovation.}

Proposition 1d: The greater a restaurant's co-ordinating capabilities, the greater the ability of and likelihood for firm innovation.

\subsection{The Mediating Role of Human Capital}

Coff \& Kryscynski (2011) defined human capital as an individual's stock of knowledge, skills, and experience. Human capital should be correctly managed so that it is in harmony with an organization's goals. A company which recognizes innovation as the key driver to achieving competitive advantage will pay more attention to employees who have demonstrated the greatest ability to innovate (Wright, Coff \& Moliterno, 2014). Thus, the generation of new ideas is as a result of human capital with high levels of knowledge, skills, and experience who question the prevailing organizational norms and emanate new ways of thinking (Subramaniam \& Youndt, 2005). Human capital practices critical in organizations include training, recruitment, selection, and compensation. Training improves employee productivity and facilitates the acquisition of new knowledge and skills that meet an organization's needs. Recruitment and selections impacts on the knowledge levels of new employees (Chang, 2014).

Ottenbacher \& Gnoch (2005) established that service innovation was less significant compared to the effectiveness obtained from the use of human capital management practices such as training and empowerment. The study findings demonstrated that innovation alone cannot lead to better restaurant performance and competitiveness. Improved performance and competitiveness require the development of capabilities such as the intangible resource of human capital embedded in dynamic capabilities. Lee et al. (2016) established that the restaurant industry recognizes human capital as the most critical resource compared to the other sectors due to its high customer interactions. Employees are responsible for the creation of new products and services. Therefore those who train, empower, and compensate their employees better than their rivals, innovate more. Stierand et al. (2014) used a systemic model of creativity and innovation to study creativity among Michelin Star chef. They found that individual creativity, as described by the chefs interviewed, was guided by their intuition and that innovation elements of the cuisines were defined by knowledge and evaluators from the highly respected restaurant guidelines such as the Michelin Star guidelines.

Restaurant managers' knowledge, skills, and capabilities need to be frequently developed through training to enable them to respond satisfactorily to dynamically changing customer requirements (Davidsson \& Honig, 2003; Nafukho, Hairston, \& Brooks, 2004). Further, possessing higher education and skills increases the management ability to explore and identify new opportunities in the market, develop strategies to pursue them which leads to an increased level of innovative capabilities. Previous empirical studies have supported a positive relationship between human capital and restaurants' levels of innovative performance (De Winne \& Sels, 2010). Improved levels of human capital increases an individual's ability to develop new ideas that lead to the development of new or improved products and services; and the discovery and exploitation of new opportunities faster than those with less industry-related knowledge and skills. Human capital, therefore, has a direct link to innovation and should be nurtured to ensure improved restaurant innovative performance

Therefore, we posit the following.

\section{Proposition 2: A restaurant's human capital will mediate the influence of dynamic capabilities on product, service, process, marketing, and management innovation}

\subsection{Innovation and Restaurant Performance}

Research on restaurant performance has mainly focused on non- financial data due to limited accessibility and availability of financial data in the public databases or stock markets for independent restaurants (Liu $\&$ Liu ,2014). The available financial data often cannot be substantiated. Financial data is mainly available for larger enterprises such as restaurant chains and franchises. Thus, the use of financial measures of performances using self-assessed subjective assessment is widely used and accepted and has been shown to have a strong correlation with objective performance measures. Such measures include growth in net profit, perceived growth in sales, perceived growth in profits, return on investment, perceived business success, and overall growth in business and meeting stakeholder expectations (Lee et al., 2016; Hallak et al., 2018). Empirical studies have supported a positive relationship between innovation activities and restaurant performance. For example, Lee et al. (2016) found a positive relationship between innovation activities, entrepreneurial self-efficacy, and restaurant performance. Their study also established that innovations in products, service, and marketing influenced the restaurants level of sales revenue while innovations in processes and management determined the level of profits. Hallak et al. (2018) established that the restaurant owner's innovation levels influenced a 
restaurant's performance.

Proposition 3: A restaurant's activities supporting product, process, service, marketing, and management innovation shall lead to improved performance.

Propositions 1-3, therefore, form the basis of the proposed research innovation model for independent restaurants. The model, shown in Figure 1, is based on dynamic capabilities, human capital, innovation, and performance. $\mathrm{P}_{1}$ to $\mathrm{P}_{3}$ in the figure correspond to propositions $1-3$, respectively.

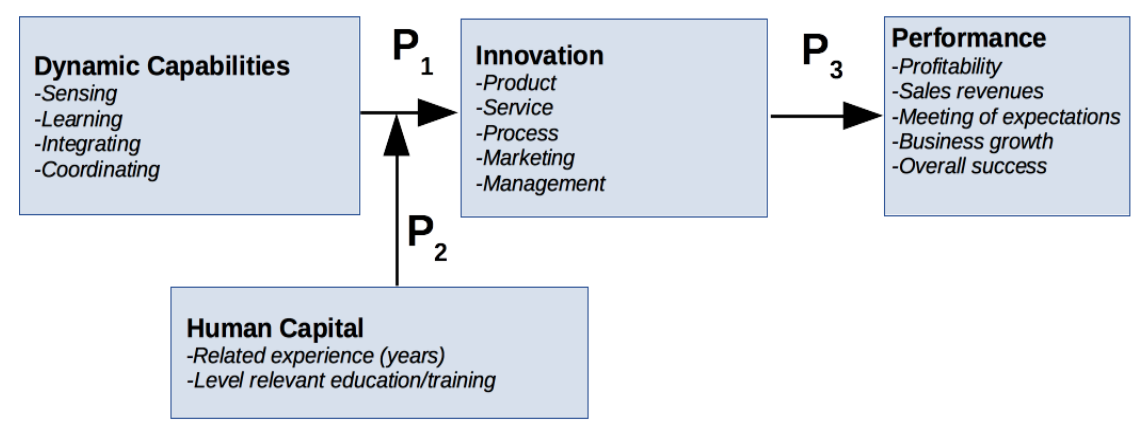

Figure 1. Research Innovation Model for Independent Restaurants

\section{Discussion}

Three empirical studies on innovation in restaurants were interrogated as case studies to establish the extent to which they support the proposed model. In the first study of Michelin-Starred Chefs, Ottenbacher \& Harrington (2007) developed an innovation process model. With reference to Figure 2(a), their model considers several input elements (product consideration, inspiration sources, screening criteria, informal market research, tacit creativity skills, cooking in your head, formalising the concept, operational issues and communication and testing) feeding into various steps of the product innovation process. The latter is presented serially as idea generation, screening, trail and error, concept development, final testing, training, and commercialization. The input elements identified by the Michelin-Starred Chefs map onto the four dynamic capability component factors (sensing, learning, integrating, and adapting capabilities) as shown in Figure 2(b), clearly demonstrating that the input elements are activities/capabilities that can be captured by the dynamics capabilities framework. Ottenbacher \& Harrington (2007) did not consider human capital or performance in their study. Although their model was based on product innovation, similar activities/capabilities and innovation process steps could be described for each of the other innovation component factors.

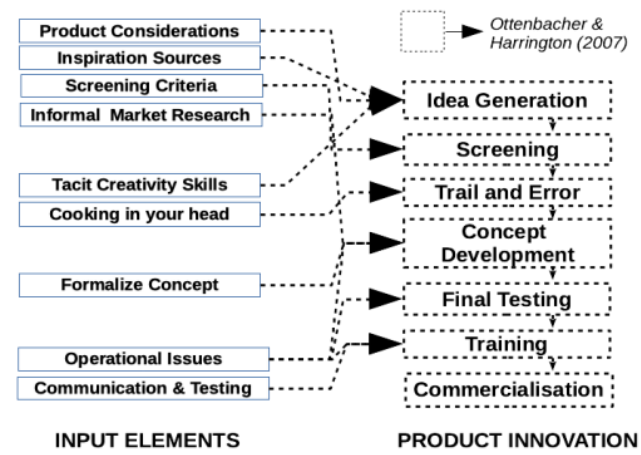

Figure 2(a). Innovation Process Model for Figure 2(b). Innovation Process Model Recast into the Restaurants (Ottenbacher \& Harrington, 2007).
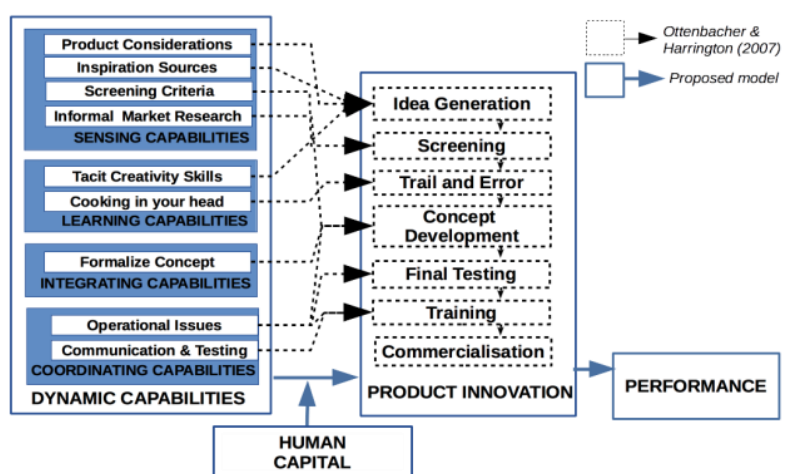

Research Innovation Model for Independent Restaurants

Lee et al. (2016) proposed a higher-order model linking entrepreneurship and innovation to small restaurant performance. In their model, based on Entrepreneurial Self-Efficacy and presented in Figure 3(a), entrepreneurial activities include. developing new product and marketing opportunities, initiating investor relationships, building an innovative environment, developing critical HR, defining shared purpose and coping with unexpected challenges. The model also interrogated the direct influence of human capital on entrepreneurship, innovation and performance. Three of the model variables (human capital, innovation, and performance) map directly onto 
the proposed research innovation model for independent restaurants (see Figure 3(b)). The entrepreneurship construct can be mapped onto the dynamic capabilities component factors as shown in Figure 3(b), lending further support to the more general proposed dynamic capabilities-based research model.

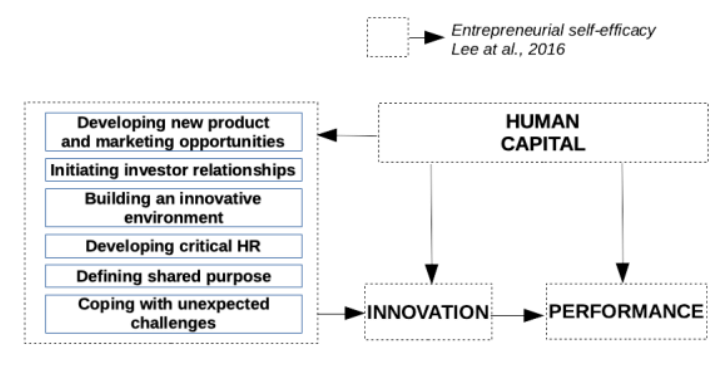

Figure 3(a). Entrepreneurial Self-Efficacy Model for Restaurants (Lee et al., 2016).

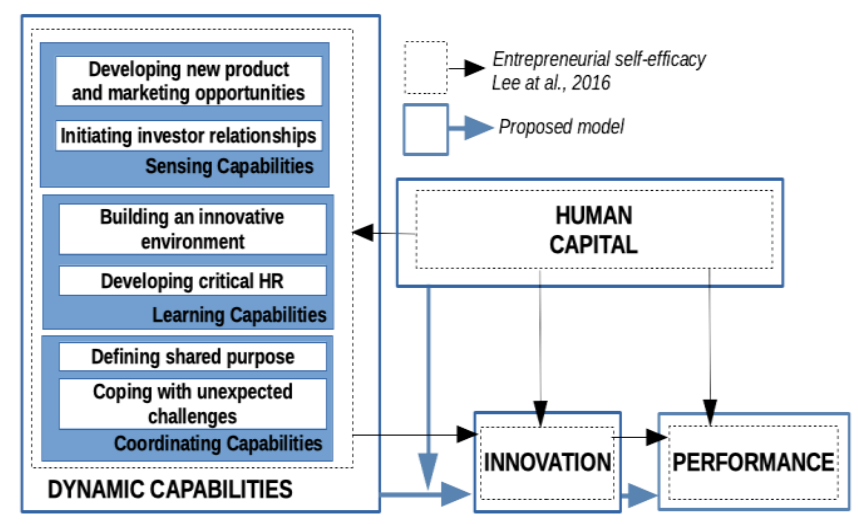

Figure 3(b). Entrepreneurial Self-Efficacy Recast into the Research Innovation Model for Independent Restaurants

The third and final empirical model interrogated was the higher-order model proposed by Hallak et al. (2018) that looked at the effect of creative self-efficacy (CSE) and resilience on innovation and performance (see Figure 4(a)) The restaurant owner's experience (human capital) was treated as a mediating variable as shown. The CSE and resilience constructs can be mapped onto the dynamic capabilities component factors as shown in Figure 4(b). The three variables of human capital (conceptualised as owner's experience), innovation, performance map directly onto the proposed research innovation model for independent restaurants. The three case studies demonstrate the applicability of the proposed model for the empirical studies of innovation and performance in restaurants coupled with the mediating role of human capital and the antecedents of innovation based on a dynamic capabilities framework. Also, one of the challenges faced with the use of a dynamic capabilities framework is the correct identification of suitable activities that best capture each of the four capabilities within the industry under study. From the case study analysis, the activities empirically found to be suitable for the restaurant sector are compiled as shown in Table 2. The compilation serves as a starting point for identification of appropriate activities when conducting research on the sector based on a dynamic capabilities approach.

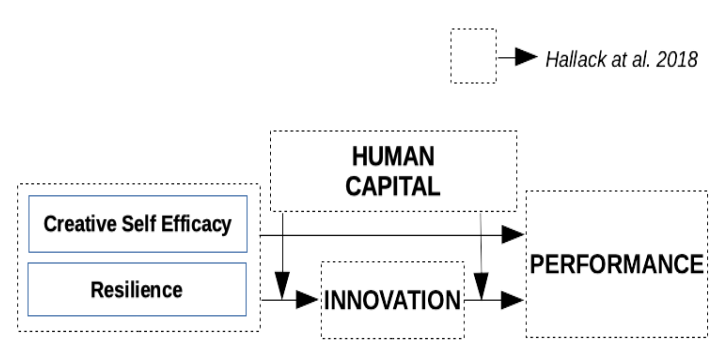

Figure 4(a). Creative Self-Efficacy and Resilience Model for Restaurants (Hallack et al., 2018).

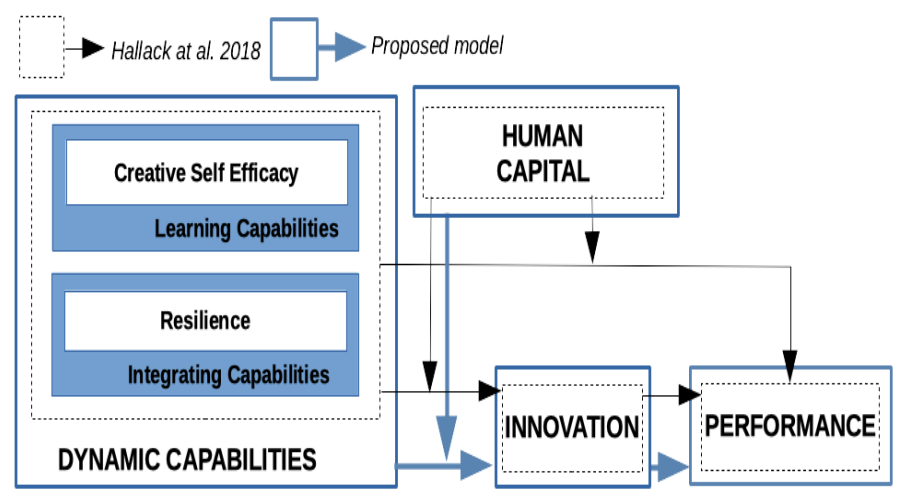

Figure 4(b). Creative Self-Efficacy and Resilience Recast into the Research Innovation Model for Independent Restaurants 
Table 2. Dynamic Capabilities Activities and Capabilities Applicable in the Restaurant Sector

\begin{tabular}{llll}
\hline Sensing Capabilities & Learning Capabilities & Integrating Capabilities & Coordinating Capabilities \\
\hline $\begin{array}{l}\text { Developing new product } \\
\text { capabilities }\end{array}$ & Building an innovative & Formalise concept & $\begin{array}{l}\text { Defining shared purpose } \\
\text { Coping with unexpected } \\
\text { Initiating investor }\end{array}$ \\
relationships & Developing critical HR & Resilence & Operational issues \\
Product considerations & Tacit creativity skills & & Communication and testing \\
Inspiration sources & Cooking in your head & & \\
Screening criteria & Creating self-efficacy & & \\
Informal market research & & & \\
\hline
\end{tabular}

\section{Conclusion}

The proposed dynamic capabilities-based innovation research model for restaurants provides a general framework for studying innovation, its antecedents represented by dynamic capabilities, and innovation. The model has the potential to be widely applicable as demonstrated through the case studies. It should be tested by researchers to confirm its applicability and impact in the restaurant sector and also enrich knowledge on dynamic capabilities research. The study also recognized the importance of human capital and its mediating role on innovation and performance Various testable propositions were proposed forming a foundation for the creation of new knowledge and building of dynamic capabilities research in the restaurant industry.

\section{References}

Assaf, A. G., Deery, M., \& Jago, L. (2011). Evaluating the performance and scale characteristics of the Australian restaurant industry. Journal of Hospitality \& Tourism Research, 35(4), 419-436. https://doi.org/10.1177/1096348010380598

Ayala, J. C., \& Manzano, G. (2014). The resilience of the entrepreneur. Influence on the success of the business. A longitudinal analysis. Journal of Economic Psychology, 42, 126-135. https://doi.org/10.1016/j.joep.2014.02.004

Camisón, C., \& Monfort-Mir, V. M. (2012). Measuring innovation in tourism from the Schumpeterian and the dynamic capabilities perspectives. Tourism Management, 33, 776-789. https://doi.org/10.1016/j.tourman.2011.08.012

Coff, R., \& Kryscynski, D. (2011). Invited editorial: Drilling for micro-foundations of human capital-based competitive advantages. Journal of management, 37(5), 1429-1443. https://doi.org/10.1177/0149206310397772

Davidsson, P., \& Honig, B. (2003). The role of social and human capital among nascent entrepreneurs. Journal of business venturing, 18(3), 301-331. https://doi.org/10.1016/S0883-9026(02)00097-6

De Winne, S., \& Sels, L. (2010). Interrelationships between human capital, HRM and innovation in Belgian start-ups aiming at an innovation strategy. The International Journal of Human Resource Management, 21(11), 1863-1883. https://doi.org/10.1080/09585192.2010.505088

Eisenhardt, K. M., \& Martin, J. A. (2000). Dynamic capabilities: what are they?. Strategic management journal, 21(10-11), 1105-1121. https://doi.org/10.1002/1097-0266(200010/11)21:10/11<1105::AID-SMJ133>3.0.CO;2-E

Gill, A. S. (2008). The role of trust in the employee-manager relationship. International Journal of Contemporary Hospitality Management, 20(1), 98-103. https://doi.org/10.1108/09596110810848613

Gordon, S., \& Parikh, A. (2021). Supporting employee well-being: The case of independent restaurants. Journal of Foodservice Business Research, 24(2), 215-234. https://doi.org/10.1080/15378020.2020.1842956

Gunday, G., Ulusoy, G., Kilic, K., \& Alpkan, L. (2011). Effects of innovation types on firm performance. International Journal of production economics, 133(2), 662-676. https://doi.org/10.1016/j.ijpe.2011.05.014

Hall, C. M. (2009). Innovation and tourism policy in Australia and New Zealand: never the twain shall meet? Journal of Policy Research in Tourism, Leisure and Events, 1(1), 2-18. https://doi.org/10.1080/19407960802703466

Hall, C. M. (2009). Innovation and tourism policy in Australia and New Zealand never the Twain Shall Meet? Journal of Policy Research in Tourism, Leisure \&Events, 1(1), 2e18. 
https://doi.org/10.1080/19407960802703466

Hallak, R., Assaker, G., O’Connor, P., \& Lee, C. (2018). Firm performance in the upscale restaurant sector: The effects of resilience, creative self-efficacy, innovation and industry experience. Journal of Retailing and Consumer Services, 40, 229-240. https://doi.org/10.1016/j.jretconser.2017.10.014

Harrington, R. J. (2005). Part I: the culinary innovation process-a barrier to imitation. Journal of Foodservice Business Research, 7(3), 35-57. https://doi.org/10.1300/J369v07n03_04

Helfat, C. E., \& Peteraf, M. A. (2003). The dynamic resource-based view: Capability lifecycles. Strategic management journal, 24(10), 997-1010.

Hjalager, A. M. (2010). A review of innovation research in tourism. Tourism Management, 31(1), 1-12. https://doi.org/10.1016/j.tourman.2009.08.012

Hussain, K., Konar, R., \& Ali, F. (2016). Measuring service innovation performance through team culture and knowledge sharing behaviour in hotel services: a PLS approach. Procedia-Social and Behavioral Sciences, 224, 35-43. https://doi.org/10.1016/j.sbspro.2016.05.397

Kato, M., Okamuro, H., \& Honjo, Y. (2015). Does Founders' Human Capital Matter for Innovation? Evidence from Japanese Start-ups. Journal of Small Business Management, 53(1), 114-128.

https://doi.org/10.1111/jsbm.12094

KNBS. (2018). Economic Survey, Nairobi: Government Printers.

Lee, C., Hallak, R., \& Sardeshmukh, S. R. (2016). Innovation, entrepreneurship, and restaurant performance: A higher-order structural model. Tourism Management, 53, 215-228.

https://doi.org/10.1016/j.tourman.2015.09.017

Lee, C., Hallak, R., \& Sardeshmukh, S. R. (2019). Creativity and innovation in the restaurant sector: Supply-side processes and barriers to implementation. Tourism Management Perspectives, 31, 54-62.

https://doi.org/10.1016/j.tmp.2019.03.011

Li, D. Y., \& Liu, J. (2014). Dynamic capabilities, environmental dynamism, and competitive advantage: Evidence from China. Journal of Business Research, 67(1), 2793-2799. https://doi.org/10.1016/j.jbusres.2012.08.007

Liu, H., Li, H., DiPietro, R. B., \& Levitt, J. A. (2018). The role of authenticity in mainstream ethnic restaurants: Evidence from an independent full-service Italian restaurant. International Journal of Contemporary Hospitality Management. https://doi.org/10.1108/JJCHM-08-2016-0410

Muriuki, B. K., \& Ogot, M. (2018). Online food ordering among food outlets in Nairobi. AJBUMA JOURNAL, $4(1)$.

Nafukho, F. M., Hairston, N., \& Brooks, K. (2004). Human capital theory: Implications for human resource development. Human Resource Development International, 7(4), 545-551. https://doi.org/10.1080/1367886042000299843

Okhuysen, G. A., \& Eisenhardt, K. M. (2002). Integrating knowledge in groups: How formal interventions enable flexibility. Organizational Science, 13(4), 370-386. https://doi.org/10.1287/orsc.13.4.370.2947

O'Sullivan, D., \& Dooley, L. (2009). Applying Innovation. (I. SAGE Publications, Ed.). The United Kingdom.

Otengei, S. O., Bakunda, G., Ngoma, M., Ntayi, J. M., \& Munene, J. C. (2017). Internationalization of African-ethnic restaurants: A qualitative enquiry using the dynamic capabilities perspective. Tourism Management Perspectives, 21, 85-99. https://doi.org/10.1016/j.tmp.2016.12.001

Ottenbacher, M. C., \& Harrington, R. J. (2009). The product innovation process of quick-service restaurant chains. International Journal of Contemporary Hospitality Management. https://doi.org/10.1108/09596110910967782

Ottenbacher, M., \& Gnoth, J. (2005). How to develop successful hospitality innovation. Cornell Hotel and Restaurant Administration Quarterly, 46(2), 205-222. https://doi.org/10.1177/0010880404271097

Ottenbacher, M., \& Harrington, R. J. (2007). The innovation development process of Michelin-starred chefs. International Journal of Contemporary Hospitality Management, 19(6), 444-460. https://doi.org/10.1108/09596110710775110

Pavlou, P. A., \& El Sawy, O. A. (2011). Understanding the elusive black box of dynamic capabilities. Decision Sciences, 42(1), 239-273. https://doi.org/10.1111/j.1540-5915.2010.00287.x 
Rodgers, S. (2007). Innovation in foodservice technology and its strategic role. International Journal of Hospitality Management, 26(4), 899-912. https://doi.org/10.1016/j.ijhm.2006.10.001

Ryu, K., \& Han, H. (2010). Influence of the quality of food, service, and physical environment on customer satisfaction and behavioural intention in quick-casual restaurants: Moderating role of perceived price. Journal of Hospitality \& Tourism Research, 34(3), 310-329. https://doi.org/10.1177/1096348009350624

Saad Andaleeb, S., \& Conway, C. (2006). Customer satisfaction in the restaurant industry: an examination of the transaction-specific model. Journal of services marketing, 20(1), 3-11. https://doi.org/10.1108/08876040610646536

Salunke, S., Weerawardena, J., \& McColl-Kennedy, J. R. (2011). Towards a model of dynamic capabilities in innovation-based competitive strategy: Insights from project-oriented service firms. Industrial Marketing Management, 40(8), 1251-1263. https://doi.org/10.1016/j.indmarman.2011.10.009

Schilke, O., Hu, S., \& Helfat, C. E. (2018). Quo Vadis, dynamic capabilities? A content-analytic review of the current state of knowledge and recommendations for future research. Academy of Management Annals, 12(1), 390-439. https://doi.org/10.5465/annals.2016.0014

Singal, M. (2015). How is the hospitality and tourism industry different? An empirical test of some structural characteristics. International Journal of Hospitality Management, 47, 116-119. https://doi.org/10.1016/j.ijhm.2015.03.006

Stierand, M., Dörfler, V., \& MacBryde, J. (2014). Creativity and Innovation in Haute Cuisine: Towards a Systemic Model. Creativity and Innovation Management, 23(1), 15-28. https://doi.org/10.1111/caim.12050

Subramaniam, M., \& Youndt, M. A. (2005). The influence of intellectual capital on the types of innovative capabilities. Academy of Management Journal, 48(3), 450-463. https://doi.org/10.5465/amj.2005.17407911

Teece, D. J. (2007). Explicating dynamic capabilities: the nature and microfoundations of (sustainable) enterprise performance. Strategic management journal, 28(13), 1319-1350. https://doi.org/10.1002/smj.640

Teece, D. J. (2014). The foundations of enterprise performance: Dynamic and ordinary capabilities in an (economic) theory of firms. Academy of Management Perspectives, 28(4), 328-352. https://doi.org/10.5465/amp.2013.0116

Teece, D. J., Pisano, G., \& Shuen, A. (1997). Dynamic capabilities and strategic management. Strategic management journal, 18(7), 509-533. https://doi.org/10.1002/(SICI)1097-0266(199708)18:7<509::AID-SMJ882>3.0.CO;2-Z

Valeri, M., \& Baggio, R. (2021). Increasing the efficiency of knowledge transfer in Italian tourism system: a network approach. Current Issues in Tourism. https://doi.org/10.1080/13683500.2021.1937960

Van Riel, A. C., Victorino, L., Verma, R., Plaschka, G., \& Dev, C. (2005). Service innovation and customer choices in the hospitality industry. Managing Service Quality: An International JournalWall, E. A., \& Berry, L. https://doi.org/10.1108/09604520510634023

Wall, E. A., \& Berry, L. L. (2007). The combined effects of the physical environment and employee behaviour on customer perception of restaurant service quality. Cornell Hotel and restaurant administration quarterly, 48(1), 59-69. https://doi.org/10.1177/0010880406297246

Wang, C. L., \& Ahmed, P. K. (2004). The development and validation of the organisational innovativeness construct using confirmatory factor analysis. European Journal of Innovation Management, 7(4), 303-313. https://doi.org/10.1108/14601060410565056

Wright, P. M., Coff, R., \& Moliterno, T. P. (2014). Strategic human capital: Crossing the great divide. Journal of Management, 40(2), 353-370. https://doi.org/10.1177/0149206313518437

Zahra, S. A., \& George, G. (2002). Absorptive capacity: A review, reconceptualization, and extension. Academy of Management Review, 27(2), 185-203. https://doi.org/10.2307/4134351

Zahra, S. A., Sapienza, H. J., \& Davidsson, P. (2006). Entrepreneurship and dynamic capabilities: A review, model and research agenda. Journal of Management studies, 43(4), 917-955. https://doi.org/10.1111/j.1467-6486.2006.00616.x

Zhou, Y., Hong, Y., \& Liu, J. (2013). Internal commitment or external collaboration? The impact of human resource management systems on firm innovation and performance. Human Resource Management, 52, 263-288. https://doi.org/10.1002/hrm.21527 
Zollo, M., \& Winter, S. G. (2002). Deliberate learning and the evolution of dynamic capabilities. Organization Science, 13(3), 339-351. https://doi.org/10.1287/orsc.13.3.339.2780

\section{Copyrights}

Copyright for this article is retained by the author(s), with first publication rights granted to the journal.

This is an open-access article distributed under the terms and conditions of the Creative Commons Attribution license (http://creativecommons.org/licenses/by/4.0/). 